\title{
CONSUMERS INTEREST FOR ERGONOMIC KNOCK-DOWN WATER FILTERS
}

\author{
Gempur Santoso $^{1}$, Yoso Wiyarno ${ }^{2}$, Poniman ${ }^{3}$ \\ Industrial Engineering Department, Faculty of Industrial Technology $y^{1,2,3}$ \\ University of PGRI AdiBuana Surabaya \\ email :gempur_bohar@yahoo.com
}

\begin{abstract}
Provision of clean water is still a problem currently in Indonesia, $80 \%$ of the population still consume water that does not meet health standards. Is the ergonomic knock down water filters to provide clean water become consumer interest?. The study was designed using a comparative descriptive study, The number of respondents is 30 people who use water filters. Data is taken by observation and questionnaire. Data is analyzed using descriptive percentages. The result of the research shows that the " $C$ " (Portable Water Filter Purifier) Water Filter form is the most consumers interest (40\%), " $B$ " water filter form (Indoor Drinking Water Filter Stainless Steel Water Purifier) is $(36.6 \%)$, and the least interested is form of "A" (Mi Water Purifier) water filter (23.3\%).73.3\% of respondents choose stainless steel material. Conclusion: water filter users have the highest interest in the type of portable knock down filter made of stainless steel material, easily installed and used ergonomically, and the material is not easily corrosion
\end{abstract}

Keywords: Water filter, ergonomics, knock down, consumer interest.

\section{INTRODUCTION}

Republic of Indonesia rich in water resources. In reality, many residents in some areas often experience a clean water crisis. Sometimes, the products of the Regional Water Supply Company are still muddy. As a solution to provide clean water is the provision of clean water filters. Water filters that are easy to use, can be carried anywhere, and do not damage existing pipelines are very necessary, that is ergonomic knock-down water filter form.
The availability of clean water for human health in Indonesia is still a concern. According to Scholastica Gerintya (2018) stated that in Indonesia each year as many as 1.7 million children die from diarrhea caused by an unhealthy environment, especially water. In addition, the results of research from the world bank water and sanitation consultants (Utamawaterfilter, 2014-2018) stated that up to 2017 there were around 100 million people in Indonesia at around 80\% still consuming unhealthy water.

Ergonomic knock-down water filter is a tool for producing clean water that is easy to install and move. Consumers of a product certainly have a choice according to their interests. The selection of a product cannot be separated from several attribute criteria, including: shape, weight, size, material and others. Gitosudarno, et al (1995) states that a component that is the properties of the product so that the product can meet the needs and desires expected by the buyer (user / consumer). Likewise, Suharno, et al (2010) stated that product attributes that need to be offered such as quality, features, style and design.

Thedy Yogasara (2003) in his research on consumer interest in a telephone product design, respondents were interested in having a criteria cell phone: model and size, color, shape, and telephone platform. Of course in other products such as water filters consumer interest has the desired criteria. Ferdinand's (2018) research results stated that the consumers interest was caused by brand variables, brand image, product shape, color, and label by $51.3 \%$ while the remaining $48.7 \%$ was caused by other variables. Therefore, a product before being designed and marketed should know consumer interest in the product. 
This study focuses on consumers interest to the ergonomic knock-down water filter form. Thus, the form of filters that consumers are interested in will eventually be produced. This is a contribution to the solution for the procurement and supply of clean water for the community.

\section{METHODOLOGY}

The study was designed using a comparative descriptive study. The research data was taken using

observation and questionnaire. Secondary data using literature studies. Research respondents are

consumers with a user (consumer) water filter background. Using sample of 30 respondents. After the data is collected, it is analyzed using descriptive percentages.

\section{ANALYSIS AND DISCUSSION}

In this study there are 3 forms of filters offered to consumers (respondents), namely water filters in the form of $\mathrm{A}, \mathrm{B}$, and $\mathrm{C}$. Water filters in the form of $\mathrm{A}$ : Me Water Purifier, rectangular square box. This filter has a high flow, because without a storage tank. An RO filter design. So that pure fresh water can be drunk directly from the tap. B form water filter: Indoor Drinking Water Filter Stainless Steel Water Purifier, which is a long cylindrical long faucet. Is a ceramic material filter that can filter particles 0.2-0.5 microns. Type $\mathrm{C}$ water filter: Portable Water Filter Purifier, is cylindrical portabable knock down round shape. This filter is made of high strength aluminum alloy, not corrosive, not oxidizing, and can be used in any environment.

Furthermore, based on the results of the calculation of interest data in the form of water filters (see table 1) that the C-form Water Filters are the most in demand by consumers $(40 \%)$, the form of filter B below is slightly (36.6\%), and the least amount of filter form A (23.3\%).

Table 1. Large Interest in the Form of Water Filters

\begin{tabular}{lll}
\hline Form & Large Interest & Percentage $(\%)$ \\
\hline A & 7 & 23,3 \\
B & 11 & 36,7 \\
C & 12 & 40,0 \\
Total & 30 & 100 \\
\hline
\end{tabular}

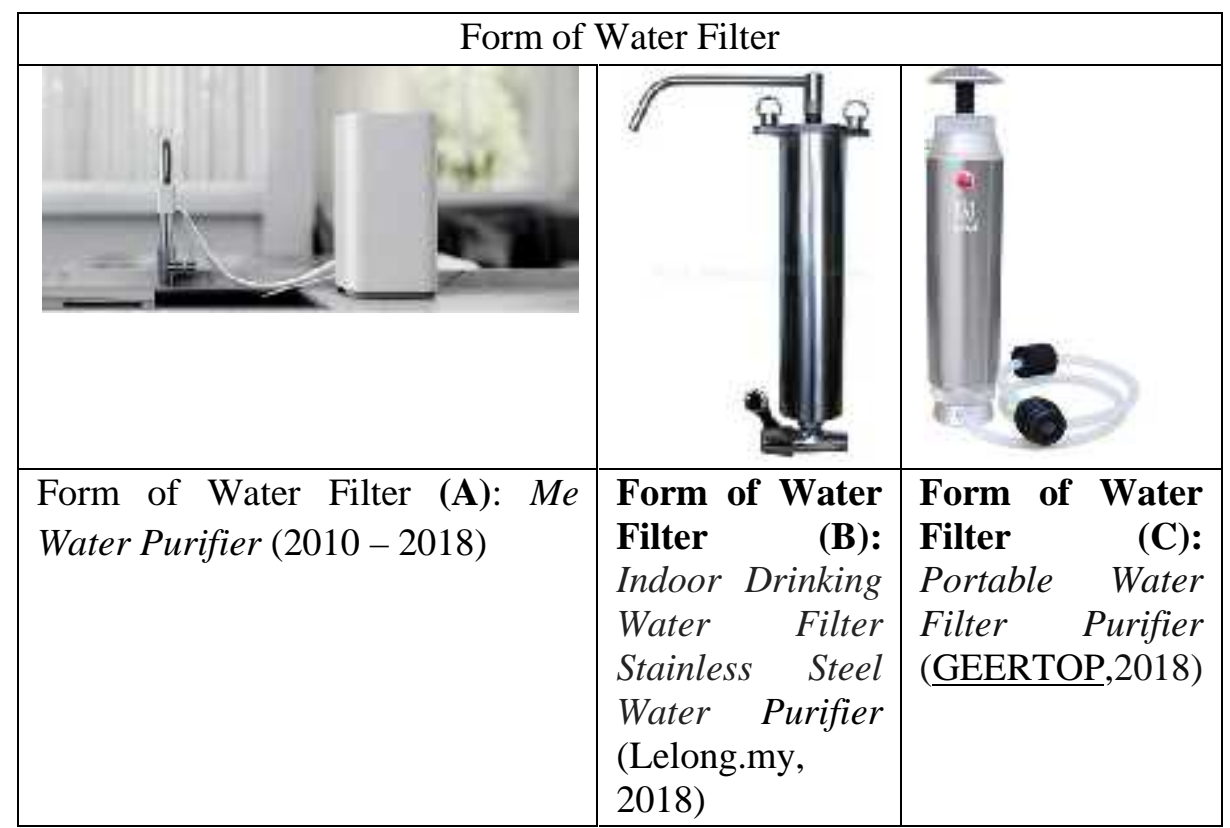

Figure 1. Form of Water Filter 


\section{Tibuana}

Journal of applied Industrial Engineering-University of PGRI Adi Buana

$p$-ISSN 2622-2027

$e$-ISSN 2622-2035

Then, in terms of consumer interest in the material water filter (see table 2). Whereas, consumers have the greatest interest in using stainless materials, namely: outer cassing

Table 2. Large Interest in Water Filter Materials

\begin{tabular}{lll}
\hline Material & Outer Material Protector & \multicolumn{1}{c}{ Inner Filter } \\
\hline Stainless & $19(63.3 \%)$ & $22(73,3 \%)$ \\
Plastic & $7(23,3 \%)$ & $6(20,0 \%)$ \\
Glass Fiber & $4(13,4 \%)$ & $2(6,7 \% \%)$ \\
Total & 30 & 30 \\
\hline
\end{tabular}

Based on the data analysis or calculation above, it can be concluded that: consumers are more interested in C-type filters, namely Portable Water Filter Purifiers. "Portable Water Filter Purifier" water filter round shaped cylindrical portabable knock down. The preferred filter material is stainless.

Properties of high strength stainless steel materials including non-corrosive and nonoxidizing. According to Logam Ceper (2017) said that stainless steel has 6 characters: high chrom content (to protect environmental influences), corrosion resistance is not easy to oxidize, low maintenance, high hardness, ductility, and white silver color.

In terms of ergonomics, cylindrical portabable knock down round water filters. Round shape is a form that does not accidentally scratch the skin. It was a preventive measure that did not cause filter users to not be scratched by cuts on their skin. Sharp and sharp-shaped objects are very

\section{CONCLUSION}

Based on the analysis and discussion that water filter users have the highest interest in choosing a portable knonck down type filter made of stainless steel material. That is, the

\section{REFERENCES}

1. Diane Ingle, 2014, Workplace effeciency improved with ergonomics, Occupational nurce educator public heath office, USA.

2. Gitosudarmo, Indriyo. 1995. Manajemen Pemasaran. Yogyakarta: BPFE.

3. GEERTOP, 2018, GEERTOP Diercon 50000L High-Quality Portable Water Filter Purifier, 99.9999\%, REMOVABLE \& WASHABLE FILTERS, For Camping, Outdoors - Long Lift, vulnerable to people being scratched on the skin of the body. Therefore, the tapered angular water filter includes an unsafe condition.

In addition, the water filter that consumers are interested in is the cylindrical portabable knock down round shape ergonomically. The water filter is portable, light can be placed anywhere, easily installed, does not damage the installed water network. Knock down, this filter can be easily removed and easily installed again. In addition, this knok down water filter easily removes all parts, is carried in a brief manner, then reassembled where the location requires as long as there is water or a water channel. Something equipment that makes users become easy is including ergonomic equipment. This is as Diane (2014) also states that one of the principles of ergonomics is to make sure all the objects that are available are easy to use.

water fiter is easily installed and used ergonomically, and the non-oxidizing steel steinlees material does not corrode.

https://www.amazon.co.uk/GEERTOPHigh-Quality-Portable-PurifierREMOVABLE/dp/B01CY25BCS

4. Logam Ceper, 2017, Sifat-Sifat Stainless Steel, https://logamceper.com/sifat-sifatstainless-steel/

5. Lelong.my, 2018, Indoor Drinking Water Filter Stainless Steel Water Purifier, https://www.lelong.com.my/; https://www.amazon.co.uk/GEERTOPHigh-Quality-Portable-PurifierREMOVABLE/dp/B01CY25BCS 
6. Mi Water Purifier, 2010-2018, https://www.mi.com/en/water/

7. Scholastica Gerintya - 20 Maret 2018, Bagaimana Mutu dan Akses Air Bersih di Indonesia?, https://tirto.id/bagaimana-mutudan-akses-air-bersih-di-indonesia-cGrk
8. Suharno dan Sutarso, Yudi. 2010. Marketing in Practice. Yogyakarta: Graha Ilmu.

9. Utama water filter,2014-2018,Masalah Air Bersih di Indonesia Seperti Tidak Pernah Usai,

Utama

Filter,http://www.utamawaterfilter.com/ 